\title{
Efek pemberian ekstrak pituitari sapi terhadap peningkatan jumlah folikel ovarium dan konsentrasi estradiol pada tikus putih (Rattus norvegicus)
}

\author{
Indah Kesuma Siregar 1, Tongku Nizwan Siregar ${ }^{2}$, Muslim Akmal ${ }^{3}$, Sri Wahyuni ${ }^{4}$ Nazaruddin 5 , \\ Hafizuddin ${ }^{2}$, * \\ ${ }^{1}$ Program Studi Magister Kesehatan Masyarakat Veteriner, Fakultas Kedokteran Hewan, Universitas Syiah \\ Kuala, Banda Aceh, 23111 \\ ${ }^{2}$ Laboratorium Reproduksi, Fakultas Kedokteran Hewan, Universitas Syiah Kuala, Banda Aceh, 23111 \\ ${ }^{3}$ Laboratorium Histologi, Fakultas Kedokteran Hewan, Universitas Syiah Kuala, Banda Aceh, 23111 \\ ${ }^{4}$ Laboratorium Anatomi, Fakultas Kedokteran Hewan, Universitas Syiah Kuala, Banda Aceh, 23111 \\ ${ }^{5}$ Laboratorium Patologi, Fakultas Kedokteran Hewan, Universitas Syiah Kuala, Banda Aceh, 23111 \\ *Correspondence: hafizuddin_umar@unsyiah.ac.id
}

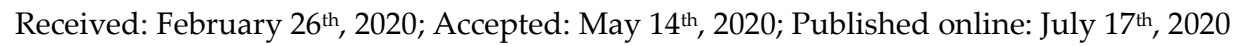

Abstrak

Tujuan: Penelitian ini bertujuan mengetahui pengaruh pemberian ekstrak pituitari terhadap peningkatan jumlah folikel dan konsentrasi estradiol pada tikus putih.

Metode: Dalam penelitian ini digunakan 10 ekor tikus putih (Rattus norvegicus) betina dewasa, galur wistar, berumur 3-4 bulan dengan bobot badan antara 200-250 g yang dibagi atas 2 kelompok. Pada kelompok kontrol, tikus diinjeksi dengan hormon PMSG (PG 600, Intervet, Boxmeer, Holland) 5 IU secara intraperitoneal. Pada kelompok perlakuan, tikus diinjeksi dengan ekstrak pituitari secara intraperitoneal selama 3 hari yakni 1,0; 0,5; dan 0,3 ml. Empat hari setelah perlakuan awal, sampel darah dikoleksi langsung dari jantung untuk pemeriksaan konsentrasi estradiol, kemudian tikus-tikus tersebut dikorbankan dengan cara dislokasio cervicalis untuk pemeriksaan mikroskopis ovarium. Penghitungan terhadap jumlah folikel dilakukan dengan menggunakan mikroskop cahaya. Penghitungan konsentrasi estradiol darah dilakukan dengan teknik enzyme-linked immunosorbent assay (ELISA). Data jumlah folikel dan konsentrasi estradiol dianalisis menggunakan uji T.

Hasil: Jumlah folikel primer, sekunder, tertier, dan CL pada kelompok PMSG vs ekstrak pituitari masing-masing adalah $3,0 \pm 1,58$ vs $4,4 \pm 3,97 ; 5,4 \pm 1,52$ vs $6,4 \pm 3,91$; dan $9,2 \pm 4,32$ vs $4,4 \pm 3,51$ buah, sedangkan konsentrasi estradiol pada kelompok PMSG vs ekstrak pituitari adalah $62,4 \pm 12,9$ vs $58,8 \pm 11,8 \mathrm{pg} / \mathrm{ml}$. Hasil penelitian menunjukkan jumlah folikel pada setiap kategori dan konsentrasi estradiol tidak memperlihatkan perbedaan secara signifikan $(\mathrm{P}>0,05)$ antar kelompok perlakuan.

Kesimpulan: Dari hasil penelitian disimpulkan bahwa ekstrak pituitari dapat meningkatkan aktivitas folikulogenesis dan konsentrasi estradiol pada tikus putih (Rattus norvegicus).

Kata Kunci: Ekstrak pituitary; PMSG; Folikel, Estradiol; Tikus putih (Rattus norvegicus).

\section{Abstract}

Objective: This study aims to determine the effect of pituitary extract administration on increasing follicle counts and estradiol concentrations in white rats. 
Methods: In this study, 10 adult female white rats (Rattus norvegicus), Wistar strains, aged 3-4 months with body weights between 200-250 g were divided into 2 groups. Control group was given 5 IU PMSG (PG 600, Intervet, Boxmeer, Holland) intraperitoneal manner, whereas the treatment group was given the pituitary extract with descending doses of 1.0; 0.5 ; and $0.3 \mathrm{ml}$, respectively. Four days after early treatments, the rats were sacrificed with dislocation cervicalis. Blood collecting for the examination of estradiol concentration and ovarium collecting for microscopic examination were collected when rats were sacrificed. Blood was collected from the heart. Follicles number was counted with the luminous microscope and estradiol concentration was measured with enzyme-linked immunosorbent assay (ELISA). Data of follicles number and estradiol concentration were analysed with $\mathrm{T}$ test.

Results: The follicles number of primary, secondary, tertiary, and CL in PMSG group vs pituitary extract, respectively was $3.0 \pm 1.58$ vs $4.4 \pm 3.97 ; 5.4 \pm 1.52$ vs $6.4 \pm 3.91$; and $9.2 \pm 4.32$ vs $4.4 \pm 3.51$ pcs. The amount of estradiol concentration in PMSG groups vs extract pituitary was $62.4 \pm 12.9$ vs $58.8 \pm 11.8$. The results of this research indicate that the number of follicles for each category and estradiol concentration were not significant differences $(\mathrm{P}>0.05)$ inter treatment groups.

Conclusions: The result from this research, it could be concluded that pituitary extract of cattle on increased of folliculogenesis activity and estradiol concentration of rats (Rattus norvegicus).

Keywords: Pituitary extract; PMSG; Follicle; Estradiol; Rats (Rattus norvegicus)

\section{PENDAHULUAN}

Superovulasi diartikan sebagai upaya
merangsang perkembangan folikel-folikel pada ovarium menjadi folikel-folikel yang siap ovulasi dan jumlahnya lebih banyak dari normal [1]. Prinsip superovulasi adalah peningkatan derajat ovulasi yang berpengaruh pada peningkatan fertilisasi dan jumlah anak per kelahiran. Superovulasi meningkatkan jumlah folikel dan korpus luteum (CL) yang merupakan sumber hormon-hormon reproduksi. Oleh karena itu, superovulasi diharapkan mampu meningkatkan hormon-hormon reproduksi yang berperan dalam peningkatan folikulogenesis dan konsentrasi estrogen.

Hormon yang paling sering digunakan untuk tujuan superovulasi adalah pregnant mare's serum gonadotropin (PMSG) dan follicle stimulating hormone (FSH). Kedua hormon tersebut masing-masing mempunyai kelebihan dan kekurangan. Hasil penelitian menunjukkan bahwa bila dibandingkan dengan penggunaan PMSG, respon ovarium terhadap hormon FSH biasanya lebih baik karena lebih banyak menghasilkan ovulasi, jumlah folikel anovulasi lebih sedikit, embrio yang dapat diperoleh lebih banyak, dan kualitas embrio lebih baik. Akan tetapi, kelemahan dari FSH adalah hormon tersebut sulit diperoleh di pasar domestik, harganya relatif mahal, dan pemberiannya harus dilakukan secara berulang sehingga mengakibatkan hewan stres [2].

Rendahnya respons superovulasi dengan PMSG diduga berhubungan dengan panjangnya masa sirkulasi PMSG sehingga menghasilkan perkembangan folikel yang berlebihan, nimfomania (berahi yang terus-menerus), dan kegagalan ovulasi. Folikel yang gagal mengalami ovulasi tersebut akan meningkatkan sekresi estrogen. Sekresi estrogen yang tinggi mempunyai efek yang merugikan terhadap perkembangan embrio [3].

Terbatasnya jumlah folikel yang mengalami ovulasi pada setiap siklus estrus pada hewan disebabkan terbatasnya jumlah hormon gonadotropin yang disekresikan oleh pituitari anterior. Hormon gonadotropin yang dimaksud adalah hormon FSH yang bertanggungjawab untuk inisiasi dan perkembangan folikel yang akan ovulasi [4].

Pituitari sapi merupakan limbah rumah potong hewan (RPH) yang mengandung hormon-hormon gonadotropin. Dari hasil penelitian Isnaini et al. [5] diketahui bahwa pituitari sapi sedikitnya mengandung 10 macam hormon diantaranya adalah $\mathrm{FSH}$, luteinizing hormone $(\mathrm{LH})$, growth hormone $(\mathrm{GH})$, luteotropic hormone (LTH), adrenocorticotropic hormone (ACTH), thyroid somatotropic hormone 
(TSH), dan prolactin hormone yang dihasilkan oleh lobus anterior pituitari. Berdasarkan kenyataan di atas, terbuka peluang bahwa ekstrak pituitari sapi dapat digunakan sebagai preparat alternatif untuk superovulasi menggantikan hormon FSH yang diekspresikan dengan munculnya respons superovulasi yang diindikasikan dengan peningkatan folikulogenesis dan konsentrasi estradiol.

Beberapa penelitian terakhir menunjukkan bahwa ekstrak pituitari sapi mampu menginduksi berahi dan meningkatkan efisiensi reproduksi kambing [6]. Pemberian ekstrak pituitari sapi pada hewan betina telah berhasil menginduksi peningkatan jumlah embrio pada tikus putih [7]. Hal tersebut membuktikan bahwa kadar FSH dalam ekstrak pituitari sapi tergolong cukup tinggi dan mempunyai efektivitas yang sama dengan gonadotropin dalam menginduksi superovulasi pada tikus. Ekstrak hipofisa sapi terbukti lebih efektif meningkatkan volume sperma ikan jika dibandingkan dengan ekstrak hipofisa kerbau dan domba. Hal ini mengindikasikan bahwa kadar FSH dalam ekstrak pituitari sapi lebih tinggi dibandingkan ekstrak pituitari kerbau dan domba [8].

Indikator untuk mengukur keberhasilan ekstrak pituitari sapi selama ini dilakukan dengan mengobservasi gejala klinis, jumlah embrio, dan jumlah anak per kelahiran [6,7]. Observasi yang lebih mendalam perlu dilakukan dengan melihat aktivitas peningkatan folikulogenesis secara mikroskopis dan pengukuran konsentrasi estradiol. Hasil pengamatan folikulogenesis secara mikroskopis dan konsentrasi estradiol merupakan acuan dasar yang tepat dalam penggunaan ekstrak pituitari sapi sebagai preparat superovulasi yang bernilai ekonomis dan praktis dengan tingkat keberhasilan yang tinggi. Oleh karena itu, perlu penelitian untuk mengetahui pengaruh pemberian ekstrak pituitari terhadap peningkatan jumlah folikel dan konsentrasi estradiol pada tikus putih.

\section{MATERI DAN METODE}

Dalam penelitian ini digunakan 10 ekor tikus putih (Rattus norvegicus) betina dewasa, galur wistar, berumur 3-4 bulan dengan bobot badan antara 200-250 g. Sebelum perlakuan, tikus diaklimatisasi selama 7 hari di kandang hewan coba Laboratorium Reproduksi Fakultas Kedokteran Hewan Universitas Syiah Kuala. Tikus diberi pakan serta air minum secara ad libitum.

\section{Prosedur penelitian}

Tikus dibagi atas 2 kelompok, masing-masing 5 ekor untuk kelompok kontrol dan 5 ekor untuk kelompok perlakuan. Pada kelompok kontrol, tikus diinjeksi dengan hormon PMSG (PG 600, Folligon $^{\mathrm{TM}}$, Intervet, Boxmeer, dan Holland) 5 IU secara intraperitoneal antara pukul 13.00-14.00 WIB. Pada kelompok perlakuan, tikus diinjeksi dengan ekstrak pituitari sapi secara intraperitoneal selama 3 hari berturut-turut dengan dosis menurun yakni 1,0; 0,5; dan 0,3 ml. Empat hari setelah perlakuan awal, tikus-tikus tersebut dikorbankan dengan cara dislocatio cervicalis. Sampel darah dikoleksi langsung dari jantung pada saat tikus dipanen. Setelah koleksi darah, dilakukan pengambilan ovarium untuk pemeriksaan mikroskopis.

\section{Prosedur ekstraksi}

Penelitian ini menggunakan pituitari sapi lokal Aceh. Ekstrak pituitari dibuat berdasarkan metode yang diterapkan Isnaini et al. [5]. Pituitari sapi dikoleksi dari Rumah Potong Hewan Kota Banda Aceh. Pituitari hasil koleksi dimasukkan dalam termos dan segera dibawa ke laboratorium untuk disimpan dalam freezer sampai jumlahnya mencukupi. Jika sudah terkumpul, pituitari dibersihkan dari jaringan ikat dan dipisahkan dari selaput luar. Setelah itu, pituitari diiris kecil-kecil $( \pm 1 \mathrm{~mm})$ dan ditumbuk sampai halus, kemudian ditambahkan aquades sebanyak $10 \mathrm{ml}$ untuk setiap gram pituitari dan selanjutnya disaring dengan kertas saring. Larutan yang diperoleh disentrifugasi dengan kecepatan 3.000 rpm selama 20 menit, kemudian supernatannya diambil. Supernatan hasil sentrifugasi merupakan ekstrak pituitari dan disimpan dalam freezer sebelum digunakan. 


\section{Pemeriksaan konsentrasi estradiol}

Prosedur analisis konsentrasi estradiol pada penelitian ini dilakukan menggunakan teknik enzymelinked immunosorbent assay (ELISA) menggunakan kit estradiol (DRG International Inc., USA).

\section{Pemeriksaan dan pengumpulan data secara mikroskopis}

Masing-masing spesimen ovarium yang mengandung folikel dan CL akan dipotong secara membujur, lalu difiksasi dengan larutan BNF 10\%. Selanjutnya dilakukan proses pembuatan preparat histologis dan diwarnai dengan Hematoksilin-Eosin (HE) [9].

\section{Proses parafinisasi jaringan (embedding)}

Masing-masing spesimen ovarium yang terdapat folikel dan CL akan dipotong secara membujur. Irisan penampang folikel dan CL dimasukkan ke dalam tissue cassete, selanjutnya dilakukan proses pembuatan sediaan histologi yang dimulai dengan proses dehidrasi. Dehidrasi dilakukan untuk penarikan air dari dalam jaringan dengan merendam secara berurutan di dalam larutan alkohol bertingkat dengan konsentrasi (70, 80, 90, 95, absolut I, absolut II, dan absolut III) $\%$ masing-masing selama 90 menit, sedangkan pada alkohol absolut dengan waktu lebih kurang 30 menit pada suhu kamar. Jaringan yang terdehidrasi dengan baik akan memperlihatkan warna jaringan lebih tua dan mengeras. Selanjutnya dilakukan proses penjernihan (clearing).

Penjernihan bertujuan untuk mengeliminir dari sisa-sisa bahan atau air yang mungkin masih terdapat dalam jaringan yaitu dengan larutan xilol I, xilol II, dan xilol III, diharapkan mampu menjernihkan jaringan dan mengisi dengan sempurna bagian-bagian jaringan yang telah terambil airnya. Waktu yang dibutuhkan masing-masing selama 45 menit pada suhu kamar dengan menggunakan xilol I, xilol II, dan xilol III. Clearing yang baik akan memperlihatkan jaringan tembus pandang/bening. Setelah proses penjernihan selesai dilakukan, selanjutnya dilakukan proses infiltrasi yang bertujuan untuk menggantikan celah yang terisi xilol dengan parafin yaitu dengan cara merendam jaringan menggunakan larutan campuran xilol dan parafin, kemudian dilanjutkan ke dalam larutan parafin I, parafin II, dan parafin III masing-masing selama 45 menit pada suhu $60^{\circ} \mathrm{C}$. selanjutnya jaringan dibenamkan di dalam parafin cair, kemudian didinginkan pada suhu kamar sehingga menjadi blok parafin.

\section{Pemotongan (sectioning)}

Jaringan blok parafin yang telah siap untuk disayat dimasukkan ke penjepit (block holder) mikrotom, selanjutnya dilakukan penyayatan secara longitudinal setebal $5 \mu \mathrm{m}$ dengan menggunakan rotary microtome. Dilakukan sayatan serial, kemudian dipindahkan ke atas permukaan air dengan suhu $38-40^{\circ} \mathrm{C}$ dalam penangas air. Irisan yang telah terentang sempurna diambil dengan objek glass sediaan yang telah diolesi dengan albumin gliserin, kemudian dikeringkan dengan alat pengering sediaan pada suhu $38-40^{\circ} \mathrm{C}$. Selanjutnya objek glass sediaan yang sudah ada jaringan (sediaan histologi) disimpan dalam inkubator pada suhu $38-40^{\circ} \mathrm{C}$ untuk penyempurnaan penempelan dengan posisi horizontal selama 24 jam.

\section{Pewarnaan (staining)}

Sayatan yang telah menempel pada objek glass sediaan dengan baik dan telah diberi label disusun dalam rak sediaan kemudian dilakukan perendaman dengan xilol sebanyak dua tahapan (deparafinisasi), dengan waktu masing-masing lima menit. Selanjutnya dilakukan proses rehidrasi secara bertingkat dengan persentase alkohol (absolut I, absolut II, 95, 90, 80, dan 70) \% masing-masing selama 5 menit dan dilanjutkan dengan merendam sediaan dalam air mengalir sampai benar-benar bersih. Sediaan dibilas dengan air destilasi. Sediaan yang telah jernih siap untuk dilakukan pewarnaan HE [9]. Proses selanjutnya adalah penarikan air dengan menggunakan alkohol bertingkat dengan konsentrasi (70, 80, 90, 95, absolut I, dan absolut II) \%. Proses penjernihan menggunakan xilol sebanyak tiga kali perendaman, dengan waktu masing-masing selama 5 menit. Sediaan histologi selanjutnya 
ditutupi dengan gelas penutup yang diberi perekat entellan.

Tipe folikel digolongkan berdasarkan perbedaan-perbedaan yang terlihat dari gambaran morfologi yang teramati. Jumlah folikel dihitung dari berbagai tahap folikulogenesis. Penghitungan jumlah folikel dan CL dilakukan pada 20 sayatan ovarium yang berasal dari sayatan serial dengan interval 5. Masing-masing sayatan diambil lima luas lapang pandang, kemudian dihitung rata-ratanya. Penghitungan terhadap jumlah folikel dilakukan dengan menggunakan mikroskop cahaya [10].

\section{Analisis data}

Data jumlah folikel dan konsentrasi estradiol dianalisis menggunakan uji $\mathrm{T}$ menggunakan program $S A S \circledR$ versi 9.4.

\section{HASIL DAN PEMBAHASAN}

Karakteristik masing-masing tahapan perkembangan folikel dari hasil penelitian disajikan pada Gambar 1. Folikel yang diamati adalah folikel primer, sekunder, dan tertier. Rata-rata jumlah folikel primer, sekunder, tertier, dan CL tikus putih yang mengalami induksi dengan PMSG dan ekstrak pituitari disajikan pada Tabel 1 . Jumlah folikel pada setiap kategori dan CL tidak memperlihatkan perbedaan yang signifikan $\quad(\mathrm{P}>0,05) \quad$ antar kelompok perlakuan.

Ovarium tikus dilapisi oleh satu lapisan epitel yang disebut epitel germinativum yang berbentuk pipih hingga kuboid. Di bagian profundal lapisan epitel terdapat jaringan ikat yang disebut tunika albuginea. Ovarium merupakan sumber folikel tempat ovum dibentuk. Ovarium tikus terbagi atas dua bagian yaitu korteks yang berada di superfisial dan bagian medula yang berada di bagian profundal. Pada bagian korteks banyak ditemukan berbagai tahap perkembangan folikel yang memiliki ukuran bervariasi. Masing-masing folikel mengandung satu oosit. Berdasarkan tahap perkembangannya, folikel dikategorikan menjadi tiga tahap yaitu; folikel primer, folikel sekunder, dan folikel tertier atau antral [11]. Selama perkembangan, folikel akan mengalami pertumbuhan yang melibatkan perubahan-perubahan pada sel folikel (sel granulosa), oosit primer, dan stroma di sekitar folikel. Pada bagian medulla terdiri dari jaringan ikat longgar dan banyak ditemukan pembuluh darah serta saraf. Hal yang sama juga dilaporkan [12]. Karakteristik ovarium tikus secara mikroskopis memperlihatkan adanya suatu proses perkembangan folikel yang sangat dinamis.

Hafez and Hafez [13] mengatakan bahwa perkembangan dan maturasi folikel terjadi dengan adanya folikel primordial merupakan folikel yang pertama kali ditemukan pada hewan setelah lahir dengan jumlah tertentu pada setiap spesies. Folikel tersebut ditandai dengan oosit yang dikelilingi oleh satu lapis sel pregranulosa yang berbentuk pipih, yang berkembang di bagian korteks ovarium [14].

Folikel primer ditandai dengan adanya perubahan bentuk dari satu lapis sel pregranulosa yang berbentuk pipih menjadi sel granulosa yang berbentuk kuboid [15]. Perkembangan folikel primordial menjadi folikel primer terjadi pada saat hewan mencapai pubertas [13].

Tabel 1. Respons superovulasi tikus putih yang diinduksi dengan PMSG dan ekstrak pituitari

\begin{tabular}{lcc} 
& \multicolumn{2}{c}{ Perlakuan } \\
\cline { 2 - 3 } \multicolumn{1}{c}{ Kriteria } & PMSG & Ekstrak Pituitari \\
\hline Folikel Primer & $3,0 \pm 1,58^{\mathrm{a}}$ & $4,4 \pm 3,97^{\mathrm{a}}$ \\
Folikel Sekunder & $5,4 \pm 1,52^{\mathrm{b}}$ & $6,4 \pm 3,91^{\mathrm{b}}$ \\
Folikel Tertier & $6,4 \pm 2,19^{\mathrm{c}}$ & $4,4 \pm 3,51^{\mathrm{c}}$ \\
Korpus Luteum & $9,2 \pm 4,32^{\mathrm{d}}$ & $7,4 \pm 1,52^{\mathrm{d}}$ \\
Estradiol (pg/ml) & $62,4 \pm 12,9^{\mathrm{e}}$ & $58,8 \pm 11,8^{\mathrm{e}}$ \\
\hline
\end{tabular}

$\mathrm{a}, \mathrm{b}, \mathrm{c}, \mathrm{d}, \mathrm{e}$ Superskrips yang sama pada baris yang sama memperliharkan perbedaan yang tidak signifikan $(\mathrm{P}>0.05)$. 
Folikel sekunder ditandai dengan terbentuknya dua atau lebih lapisan sel-sel granulosa dan telah terbentuk sebuah membran (zona pelusida) yang mengelilingi oosit [14]. Oosit dan sel granulosa berperan dalam proses pembentukan zona pelusida yang mengandung glikoprotein yang berperan pada proses perlekatan spermatozoa pada oosit [16]. Folikel sekunder juga dikelilingi oleh lapisan sel yang tidak beraturan yang berasal dari diferensiasi sel-sel epiteloid dari fibroblas. Sel-sel epiteloid tersebut akan membentuk sel teka interna dari folikel. Folikel sekunder dengan sel teka interna disebut folikel preantral [15]. Pada akhir tahap perkembangan folikel sekunder, sel granulosa bertambah dan memproduksi cairan yang disebut liquor folikuli dan ditimbun di antara sel-sel folikel sehingga terbentuk rongga disebut antrum folikuli yang berisi cairan folikel yang mengandung beberapa makromolekul seperti glikosaminoglikan, protein, dan hormon steroid seperti estrogen, progresteron, dan androgen [16].

Folikel tertier (folikel antral) ditandai dengan terbentuknya lebih dari lima lapis sel granulosa yang mengelilingi oosit, antrum folikuli semakin meluas, sel teka eksterna menyusun diri mengitari folikel, dan sel yang mengitari zona pelusida mulai membentuk korona radiata [14]. Diameter folikel semakin meningkat akibat adanya proliferasi sel granulosa dan sel teka, serta pembentukan antrum folikuli yang semakin membesar karena produksi cairan folikuli yang semakin meningkat pula sehingga oosit terdesak ke bagian tepi folikel. Dinding folikel semakin menipis dan akan menjadi stigma yang nantinya akan robek pada saat ovulasi. Pada kondisi inilah, folikel yang terbentuk disebut dengan folikel de Graaf [13].

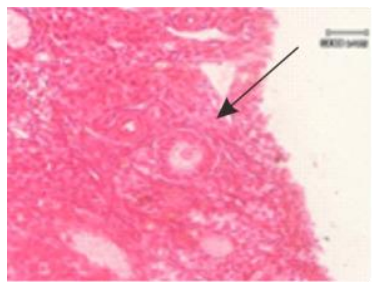

a

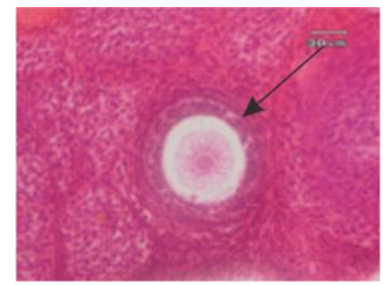

b
Hasil penelitian ini menunjukkan bahwa PMSG dan ekstrak pituitari mempunyai kemampuan yang sama dalam menginduksi folikulogenesis pada tikus putih. Pendapat tersebut didukung oleh Hafizuddin et al. [7] yang melaporkan bahwa tidak ada perbedaan kemampuan PMSG dan ekstrak pituitari sapi dalam menghasilkan embrio pada mencit. Meskipun tidak terdapat perbedaan jumlah folikel yang dihasilkan antar dua kelompok perlakuan tetapi jika dilihat secara terperinci terbukti bahwa jumlah folikel tertier yang dihasilkan hasil induksi dengan PMSG cenderung lebih banyak dibandingkan dengan ekstrak pituitari sedangkan folikel primer dan sekunder cenderung lebih banyak pada kelompok ekstrak pituitari dibandingkan kelompok PMSG. Hormon PMSG dapat menimbulkan reaksi biologi berupa reaksi superovulasi. Mekanisme kerja PMSG sebagai agen superovulasi dalam menstimulasi perkembangan folikel tambahan lainnya diantaranya melalui beberapa cara yaitu folikel kecil direkruit dan dipercepat pertumbuhannya menjadi folikel yang berkembang, jumlah folikel preantral ditingkatkan, pertumbuhan folikel antral baik yang kecil maupun yang besar ditingkatkan sehingga proporsi folikel antral yang mengalami atresi akan menurun, folikel atresi (stadium ringan) akan diselamatkan kembali supaya dapat tumbuh berkembang dan berovulasi [17]. Kondisi tersebut juga kemungkinan disebabkan pada kelompok PMSG lebih banyak folikel primer dan sekunder yang tumbuh menjadi folikel tertier karena PMSG yang digunakan dalam penelitian ini adalah PG-600 yang terdiri dari 400 IU PMSG dan 200 IU hCG. Tingginya kandungan hCG menyebabkan folikel sekunder dapat bertransformasi menjadi

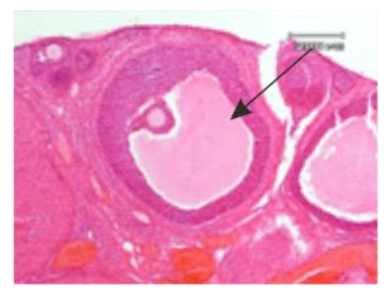

c

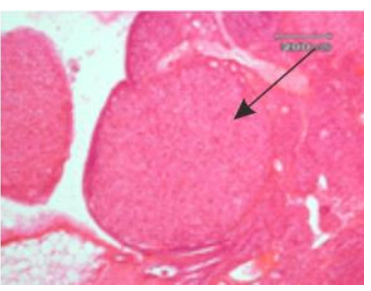
d

Gambar 1. Kategori perkembangan folikel tikus. a, folikel primer; b, folikel sekunder; c, folikel tertier; d, korpus luteum 
folikel tertier. Hormon LH (hCG) membantu proses folikulogenesis pada folikel sekunder karena folikel sekunder telah mempunyai reseptor untuk LH $[18,19]$.

Kemampuan ekstrak pituitari menginduksi folikulogenesis membuktikan pernyataan Isnaini et al. [5] bahwa pituitari mengandung hormon FSH dan LH. Bukti lain dilaporkan bahwa PMSG dan ekstrak pituitari mempunyai kemampuan yang sama dalam menginduksi kelahiran kembar pada kambing [6,20,21].

Jumlah folikel dan CL pada penelitian ini tidak dapat dijadikan sebagai rujukan hasil superovulasi pada tikus. Hal ini disebabkan jumlah folikel dan CL yang dihitung hanya pada ovarium kanan. Namun demikian, data yang disajikan dapat dijadikan perbandingan kemampuan PMSG dan ekstrak pituitari sebagai preparat superovulasi. Secara normal kadar hormon estradiol yang dihasilkan sangat tergantung pada jumlah folikel ovarium. Jika perkembangan folikel berlangsung normal maka akan dihasilkan kadar hormon yang normal juga. Sebaliknya, jika selama proses pertumbuhan dan perkembangan folikel mengalami peningkatan, maka folikel menjadi matang yang akan mempengaruhi peningkatan kadar hormon estradiol yang terbentuk [22].

Konsentrasi estradiol pada hari ke-4 setelah perlakuan awal memperlihatkan perbedaan yang tidak signifikan $(\mathrm{P}>0,05)$ seperti yang disajikan pada Tabel 1. Meskipun tidak berbeda secara statistik, tetapi bila dilihat secara terperinci konsentrasi estradiol lebih tinggi pada kelompok PMSG dibandingkan dengan kelompok ekstrak pituitari. Hormon PMSG mempunyai aktivitas seperti FSH dan sedikit LH yang mampu menstimulasi pertumbuhan dan pematangan folikel di dalam ovarium, dapat meningkatkan steroidogenesis pada ovarium yang sebagian besar adalah estrogen, androgen, dan progesteron [23]. Kondisi tersebut kemungkinan juga disebabkan pada kelompok PMSG lebih banyak terbentuk folikel tertier sehingga sekresi estradiol menjadi lebih tinggi. Folikel de Graaf yang berisi sel telur akan memproduksi hormon estrogen yang berperan dalam kejadian estrus dengan tanda-tanda yang jelas secara fisiologis [24-26].

Konsentrasi estradiol pada kedua kelompok lebih tinggi dibandingkan konsentrasi estradiol normal tikus pada hari yang sama yakni 46,65+3,31 pg/ml [27]. Peningkatan tersebut mendukung pembuktian bahwa ekstrak pituitari mengandung hormon FSH yang dapat digunakan sebagai agen superovulasi. Peningkatan konsentrasi estrogen setelah superovulasi sesuai dengan laporan Riesenberg et al. [28] dan Andriyanto et al. [29]. Konsentrasi puncak estrogen pada sapi potong dara yang diinduksi superovulasi dengan hCG adalah 46,0+11,0 pg/ml. Konsentrasi puncak diperoleh 60 jam setelah pemberian hCG yakni ketika sapi memperlihatkan gejala estrus. Peningkatan konsentrasi estrogen dihasilkan dari peningkatan pertumbuhan folikel. Veiga-Lopez et al. [30] melaporkan terdapat korelasi yang kuat antara konsentrasi estrogen pada saat berahi dengan jumlah CL. Konsentrasi estrogen sebelum superovulasi lebih rendah dari $5 \mathrm{pg} / \mathrm{ml}$, meningkat menjadi $13,6+2,1 \mathrm{pg} / \mathrm{ml}$ pada sapi yang memiliki satu CL dan $14,3+7,9 \mathrm{pg} / \mathrm{ml}$ pada sapi yang memiliki dua atau tiga CL.

\section{KESIMPULAN}

Dari hasil penelitian disimpulkan bahwa ekstrak pituitari sapi mampu meningkatkan aktivitas folikulogenesis pada tikus putih yang diindikasikan dengan peningkatan jumlah folikel dan konsentrasi estradiol.

\section{KONFLIK KEPENTINGAN}

Penulis menyatakan tidak ada konflik kepentingan dengan pihak manapun terkait materi yang ditulis dalam naskah ini.

\section{DAFTAR PUSTAKA}

1. Arum, W. P., T. N. Siregar, dan J. Melia. 2013. Efek pemberian ekstrak hipofisa sapi terhadap respons superovulasi sapi aceh. J. Med. Vet. 7:71-74. doi:10.21157/j.med.vet.v7i2.2932. 
2. Putro, P. P. 1995. Teknik superovulasi untuk transfer embrio pada sapi. Buletin FKH. UGM. 14:1-20.

3. Amiruddin, A., T. N. Siregar, T. Armansyah, H. Hamdan, dan M. Rifki. 2013. Level steroid sapi aceh yang diinduksi dengan pregnant mare's serum gonadotropin (PMSG) dan follicle stimulating hormone (FSH). J. Kedokt. Hewan. 7:120-124. doi:10.21157/j.ked.hewan.v7i2.923

4. Siregar, T. N., H. Hafizuddin, M. Akmal, D. A. Arman Sayuti, J. Melia, T. Armansyah, S. Syafruddin, B. Panjaitan, dan D. L. Adani. 2016. Follicle dynamics of Aceh cattle during estrous cycle. Glob. Vet. 17:424-429. doi:10.5829/idosi.gv.2016.424.429.

5. Isnaini, N., S. Wahjuningsih, dan G. Ciptadi. 1999. In vitro maturasi oosit sapi dalam TCM199 yang disuplementasi dengan ekstrak hipofisa sapi. J. Saintek. 7:75-85.

6. Siregar, T. N., I. K. Siregar, T. Armansyah, dan A. Sayuti. 2013. Tampilan reproduksi kambing lokal hasil induksi superovulasi dengan ekstrak pituitary sapi. J. Vet. 14:91-98.

7. Hafizuddin, H., S. Suryani, Y. Yusmadi, T. Siregar, dan T. Armansyah. 2010. Respon superovulasi mencit dengan ekstrak hipofisis: Suatu upaya menemukan agen superovulasi dengan biaya murah. Pros. Sem.Nas. Pet. Berkelanj. 4:52-56.

8. Oka, A. 2005. Penggunaan ekstrak hipofisa ternak untuk merangsang spermiasi pada ikan (Cyprinus carpio L.). Majalah Ilmiah Peternakan. 8:1-8.

9. Kiernan, J. 2015. Histological and histochemical methods: theory and practice. Scion Publishing Limited, Banbury, UK.

10. Rosadi, B., M. A. Setiadi, D. Sajuthi, dan A. Boediono. 2011. Preservasi ovarium dan pengaruhnya terhadap morfologi folikel domba. J. Vet. 12:91-97.

11. Ross, M. H. and W. Pawlina. 2016. Histology: a text and atlas: with correlated cell and molecular biology. Wolters Kluwer Health, Philadelphia, USA.

12. Kimura, J., M. Sasaki, H. Endo, and K. Fukuta. 2004. Anatomical and histological characterization of the female reproductive organs of mouse deer (Tragulidae). Placenta. 25:705-711. doi:10.1016/j.placenta.2004.02.009.

13. Hafez, E. S. E., and B. Hafez. 2000. Reproduction in farm animals. Lippincott Williams \& Wilkins, Philadelphia, US.

14. Cushman, R. A., V. S. Hedgpeth, S. E. Echternkamp, and J. H. Britt. 2000. Evaluation of numbers of microscopic and macroscopic follicles in cattle selected for twinning. J. Anim. Sci. 78:1564-1567. doi:10.2527/2000.7861564x.

15. Scaramuzzi, R. J., D. T. Baird, B. K. Campbell, M. A. Driancourt, J. Dupont, J. E. Fortune, R. B. Gilchrist, G. B. Martin, K. P. McNatty, A. S. McNeilly, P. Monget, D. Monniaux, C. Viñoles, and R. Webb. 2011. Regulation of folliculogenesis and the determination of ovulation rate in ruminants. Reprod. Fertil. Dev. 23:444-467. doi:10.1071/rd09161.

16. Mescher, A. L. 2018. Junqueira's basic histology text and atlas. McGraw-Hill Education, New York, US.

17. Dott, H., M. F. Hay, D. Cran, and R. Moor. 1979. Effect of exogenous gonadotrophin (PMSG) on the antral follicle population in the sheep. Reproduction. 56:683-689. doi:10.1530/jrf.0.0560683.

18. Yung, Y., S. Aviel-Ronen, E. Maman, N. Rubinstein, C. Avivi, R. Orvieto, and A. Hourvitz. 2014. Localization of luteinizing hormone receptor protein in the human ovary. Mol. Hum. Reprod. 20:844-849. doi:10.1093/molehr/gau041.

19. Zoheir, K. M. A., G. I. Harisa, A. A. Allam, L. Yang, X. Li, A. Liang, A. A. Abd-Rabou, and A. H. Harrath. 2017. Effect of alpha lipoic acid on in vitro development of bovine secondary preantral follicles. Theriogenology. 88:124-130. doi:10.1016/j.theriogenology.2016.09.013.

20.Zulkarnain, Sutiyono, dan E. T. Setiatin. 2015. Pemanfaatan ekstrak hipotalamus kambing sebagai upaya optimalisasi kesuburan kambing kejobong betina. J. Vet. 16:343-350.

21. Siregar, T. N. 2011. Teknologi manipulasi ovulasi secara imunologik untuk pelestarian sapi aceh dan peningkatan kesejahteraan ekonomi peternak. Banda 
Aceh.

22. Barrett, K. E., S. M. Barman, H. L. Brooks, and J. X.-J. Yuan. 2019. Ganong's review of medical physiology. McGraw-Hill Education, San Francisco, US.

23. Zhang, L., X. Zhang, Y. Lu, L. Li, and S. Cui. 2017. MiRNA-143 mediates the proliferative signaling pathway of $\mathrm{FSH}$ and regulates estradiol production. J. Endocrinol. 234:1-14. doi:10.1530/JOE-16-0488

24. Narulita, E., J. Prihatin, K. Anam, dan F. A. R. H. Oktavia. 2017. Perubahan kadar estradiol dan histologi uterus mencit (Mus musculus) betina dengan induksi progesteron sintetik. BIOSFERA. 34:117-122. doi:10.20884/1.mib.2017.34.3.487.

25. Shaw, N., S. Histed, S. Srouji, J. Yang, H. Lee, and J. Hall. 2010. Estrogen negative feedback on gonadotropin secretion: evidence for a direct pituitary effect in women. J. Clin. Endocrinol. Metab. 95:1955-1961. doi:10.1210/jc.2009-2108.

26. Grassi, S., A. Frondaroli, M. Scarduzio, C. V. Dieni, G. Brecchia, C. Boiti, and V. E. Pettorossi. 2012. Influence of sex and estrous cycle on synaptic responses of the medial vestibular nuclei in rats: role of circulating 17 $\beta$-estradiol. Brain. Res. Bull. 87:319-327.

doi:10.1016/j.brainresbull.2011.11.008.

27. Mitak, M., T. Gojmerac, B. Mandić, and Ž. Cvetnić. 2001. Changes in serum concentration of $17 \beta$-estradiol in female rats during estrous cycle after treatment with atrazine and zearalenone. Vet. Med. 46:145-148. doi:10.17221/7868-VETMED.

28. Riesenberg, S., S. Meinecke-Tillmann, and B. Meinecke. 2001. Estradiol-17beta and progesterone in the peripheral blood plasma of goats following superovulation with a single dose of pFSH, hMG or eCG. Small Ruminant Res. 40:73-82. doi:10.1016/s0921-4488(00)00212-1.

29. Andriyanto, Amrozi, M. Rahminiwati, A. Boediono, and W. Manalu. 2017. Optimum dose and time of pregnant mare serum gonadotropin injections in Kacang goats to increase endogenous secretion of estrogen and progesterone without superovulation response. Small Ruminant Res.
149:147-153. doi:10.1016/j.smallrumres.2017.02.005.

30. Veiga-Lopez, A., A. Gonzalez-Bulnes, J. A. F. Tresguerres, V. Dominguez, C. Ariznavarreta, and M. J. Cocero. 2006. Causes, characteristics and consequences of anovulatory follicles in superovulated sheep. Domest. Anim. Endocrin. 30:76-87. doi:10.1016/j.domaniend.2005.06.001. 